\title{
Geochronology of Two Mafic Intrusions in Funing, Yunnan: Implications for Its Relationships with Carlin-like Gold Mineralization
}

\author{
Pi Qiaohui ${ }^{1,2, *}$, Wei Chaowen ${ }^{1}$, Yu Huidong ${ }^{1}$, Lu Di $^{1}$ \\ ${ }^{1}$ Earth Sciences Institute, Guilin University of Technology, Guilin, China \\ ${ }^{2}$ Guangxi Key Laboratory of Hidden Metallic Ore Deposits Exploration, Guilin University of Technology, Guilin, China
}

Email address:

1481561260@qq.com (Pi Qiaohui)

${ }^{*}$ Corresponding author

\section{To cite this article:}

Pi Qiaohui, Wei Chaowen, Yu Huidong, Lu Di. Geochronology of Two Mafic Intrusions in Funing, Yunnan: Implications for Its Relationships with Carlin-like Gold Mineralization. International Journal of Mineral Processing and Extractive Metallurgy. Vol. 5, No. 1, 2020, pp. 7-19. doi: 10.11648/j.ijmpem.20200501.12

Received: February 26, 2020; Accepted: March 17, 2020; Published: April 8, 2020

\begin{abstract}
The relationship between mafic intrusion and gold deposits has always received substantial attention. Based on the petrography, mineralogy, and chronology of two mafic intrusion suites exposed in the Funing area, we found that the mafic intrusion suites have closely relationship with gold mineralization. The $255 \pm 4.9-\mathrm{Ma} \mathrm{U}-\mathrm{Pb}$ age of the early mafic intrusion suite is much older than the 218.9 $\pm 6.4-\mathrm{Ma}(\mathrm{MSWD}=1.2) \mathrm{U}-\mathrm{Pb}$ age of the late mafic intrusion suite. Based on previous studies on former gold mines in the area, it is believed that early mafic intrusion suite appears to have contributed to the early hydrothermal enrichment of gold deposits through the action of water-rock, together with atmospheric precipitation and stratigraphic water. Due to favorable structural conditions during the Indosinian tectonic period, the late basic rock not only extracted metallogenic materials from the stratum but also acted as an important heat source for the metallogenic fluid circulation and mineralization, together with superposed mineralization of frequent tectonic activities on early deposits, finally forming into ore deposits in favorable structures. Therefore, we believe that the mafic intrusion suite in the late period of the region are closely related to the gold mineralization in the region, and it can be used as a prospecting mark for gold deposits in the area.
\end{abstract}

Keywords: Mafic Intrusion, Zirconu-Pb Dating, Gold Deposit

\section{Introduction}

The relationship between mafic intrusion and gold mineralization has been a key topic for economic geologists. Many workers in China and internationally have used the mafic intrusion lamprophyre as an indicator of gold deposits [1-5]. In addition, many recent studies have shown that mafic intrusion are closely related to gold deposits [6-8]. For example, in the research of Carlin-type gold deposits by workers in China and around the world, it was found that some Carlin-type gold deposits are closely related to basic magma activities [9-14]. The activity of mantle fluids has been found evident in the formation of gold deposits such as the Laozhaiwan Gold Mine in southeastern Yunnan [15], the Baguamiao Gold Mine in Fengshan County, Shaanxi Province [16-17], and the Wangu Gold Mine [18-19]. In Hunan
Province, the basicity of the rock plays an important role in the formation of gold deposits [20-21]. For some gold deposits, the mantle fluid in the basic magma is not only a part of the ore-forming material but also an important source of ore-forming fluids [22-24]. In addition, mafic intrusion and gold mines are closely related in time and space [25-28].

According to the existing gold deposit research, gold deposits in the Funing area show a close relationship with Indosinian-age mafic intrusion, and the precipitation of gold is related to the two-stage mafic intrusion. The Funing area contains two mafic intrusion suites, one early and one late, according to the Funing area regional geological survey report [29]. The mafic intrusion considered in the present study are classified herein as follows: the early mafic intrusion suite is a Middle Triassic alkaline intrusive rock of broad geographic extent, and the late basic intrusive rock suite's geographic 
extent is rather smaller. These intrusive rocks, some containing xenoliths [30-31], invaded faults and fold belts of the Carboniferous, Permian, and Lower and Middle Triassic strata. There are several different views on the genesis of mafic intrusion in the Funing area. One view is that mafic intrusion in the area are related to the suture zone of the South China plate and the Indosinian plate, which passes through Funing [32-34]. Another view posits that the mafic intrusion in the Funing area are closely related to the post-arc rift basin system formed by the expansion of the continental margin rift [35-36]. In the Permo-Triassic, the Funing area is part of the post-arc rift basin formed by the expansion of the continental marginal rift [37-40]; this fact indirectly supports the post-arc rift basin view. A third view notes that the Funing area is located in the outer zone of the Emeishan Large Igneous Province (ELIP) [41], relating the formation time and geochemical properties of mafic intrusion to the ELIP [42]. This view asserts that the mafic intrusion in this area is the product of the combination of the geostrophic column of ELIP with Tethys subduction [43].

In summary, past authors have studied the mafic intrusion in the Funing area extensively. In this body of work, the research on the early mafic intrusion suite is more in-depth, while research is lacking for the late mafic intrusion suite. The geochemical properties of Funing's two-phase mafic intrusion are even more direly lacking. This paper will leverage past research to comprehensively compare the geochemical properties of the two mafic intrusion suites, and will integrate structural data to analyze the genesis of the late mafic intrusion suite. On this basis, the question of genesis of several gold deposits in this area will be addressed. Based on past work, a coupling relationship exists between Funing area gold deposits and the late mafic intrusion suite, not only in time and space but in geochemistry as well. If this connection can be established mechanistically, then occurrences of the late mafic intrusion suite could provide a solid basis for further prospecting.

\section{Geological Background}

Tectonically speaking, the Funing County study area is located on the southwestern margin of the South China block. It belongs to the western margin of the Caledonian fold system in South China, with the Wenshan-Funing fold bundle in the west. The overall tectonic line of the area trends northwest, while the local tectonic line trends northeast. Most faults in the area are compression-torsion faults, suggesting that the area has been strongly squeezed from the southeast. The Funing area is located in the Youjiang Basin, and the Youjiang Basin is located on the southwestern margin of the Yangtze block, recording the subduction and closure of the Paleo-Tethys branch basin [44-45]. Deep-water strata in this area include mainly Cambrian, Devonian, Carboniferous, Permian, Triassic, Tertiary, and Quaternary rocks, though there is no Lower Cambrian record. Also absent are Lower Ordovician, Silurian, and Cretaceous rocks (Figure 1).

The early mafic intrusion are mostly Ti- gabbro-diabase facies, which cause thermal metamorphism when they are in contact with surrounding rocks. Because of the varying compositions of the host rocks, the metamorphic rocks also vary. This variety manifests mainly as zoisitization of plagioclase, sericitization, and epidotization. Titanaugite is replaced by amphibole, chlorite, and clay minerals; olivine is replaced by serpentine and saponite; and biotite is replaced by chlorite or smectite. It is worth noting that some of the early mafic intrusion in the area contain pyrite, arsenopyrite, and a small amount of other sulfides such as ferrous ore, galena, and sphalerite.

The late basic intrusive rock suite is divided into four facies belts as follows: the dense diabase facies belt $(\beta \mu \mathrm{a})$, the gabbro facies belt ( $v-v a b)$, and the diorite facies belt ( $\delta b)$ [29]. The country rocks between the facies belts show varying degrees of alteration [46]. The rock composition is mainly plagioclase, pyroxene, hornblende, and biotite, with a small amount of magnetite. The metamorphic structures observed include a gabbro structure, a diaphoric structure, and a long inlaid crystal structure, along with obvious plagioclase, sericitization, epidotization, and smectitization. The late mafic intrusion suite is generally dark grayish green, and only the pyroxene diorite is gray. Three joint sets occur, the joint set consistent with the surrounding rock being the most strongly developed. The late mafic intrusion generally show spherical weathering and contain yellow metal sulfides. The gabbronorite is relatively enriched in blocky metal sulfides. Only the olivine-gabbronorite shows inconspicuous strip structures. The strips are composed of orientations of minerals and are consistent with the surrounding rock.

The late mafic intrusion suite is closely related to the distribution of economic minerals in this area (Figure 1). The regional economic minerals are mainly gold minerals, with more than 10 gold mineral-producing areas, mostly distributed in the exposed parts of the gabbro and diabase. The distribution of gold deposits and ore outcrops in the area is clearly controlled by structures, strata, and igneous rocks. In general, mineralization is concentrated at the contact zones of different lithofacies. Ore minerals include pyrite, arsenopyrite, and a small amount of limonite, as well as trace amounts of chalcopyrite, beryl, and sphalerite [47-48]. 


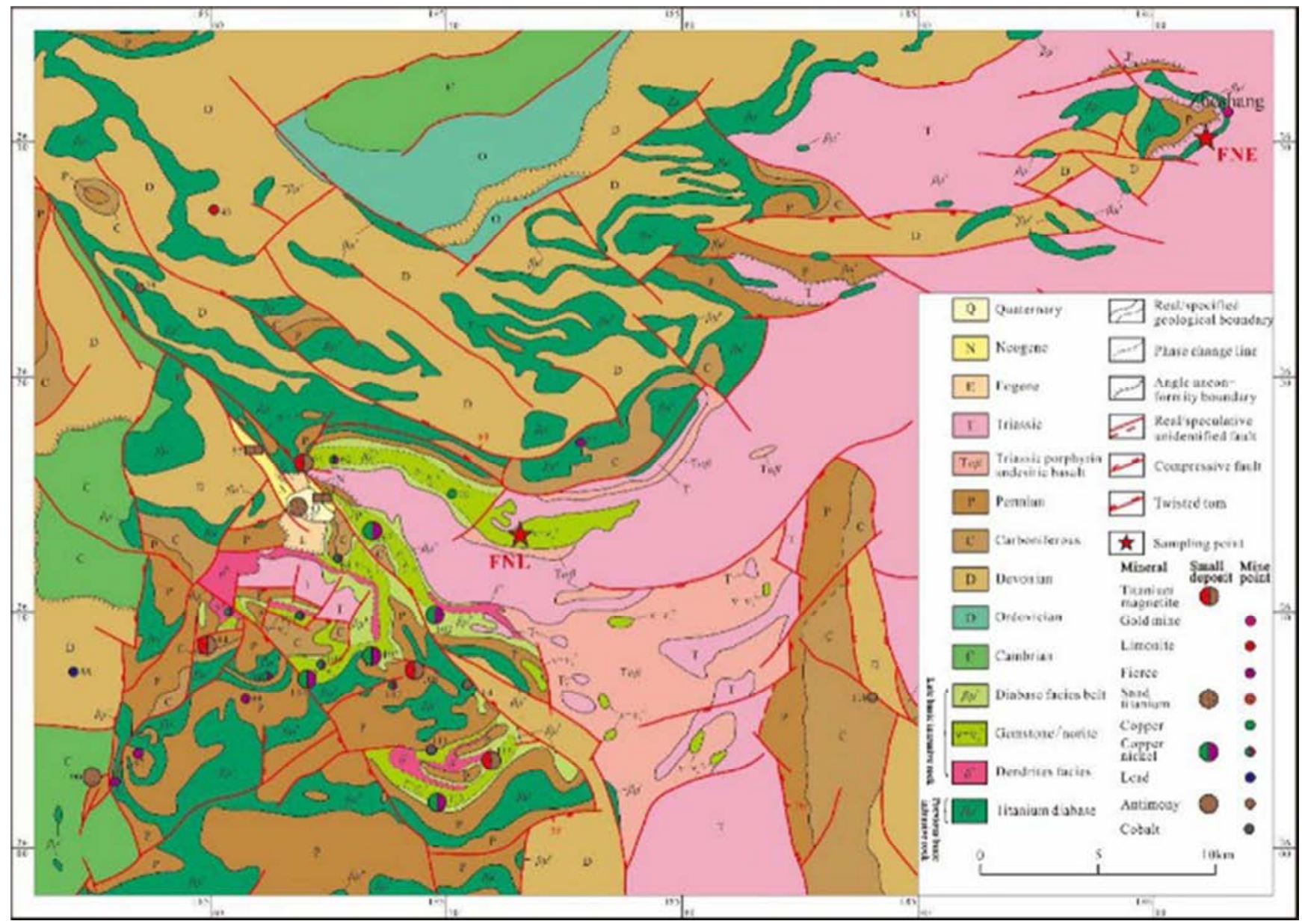

Figure 1. Distribution Diagram of mafic intrusion and mineral of Fu Ning and Sampling point (modified after Shao [49].

\section{Sampling and Analysis test Methods}

\subsection{Sampling}

In this study, samples were taken in the Funing area, collected from the most representative and minimally altered intrusive mafic intrusion outcrop areas. Samples of the early mafic intrusion suite (Figure 1, FNE) were collected near the Zheshang Gold Mine. The samples of late mafic intrusion samples (Figure 1, FNL) were collected from the sampling point.

\subsection{Analysis}

X-ray element mapping was undertaken at the Guilin University of Technology Geological Engineering Center Laboratory using a JXA8230 fitted with an Oxford Instruments Link Analytical energy dispersive X-ray spectrometer (Tri). All X-ray element maps were collected on the same instrument using the same operating conditions, with a pixel size of $\sim 0.25 \mathrm{~lm}$ and counting time of $50 \mathrm{~ms}$ per pixel. A list of captured data elements is provided in Table 1.

Sample crushing and zircon selection were completed at Langfang Chengxin Geological Service Co., Ltd. Cathodoluminescence imaging of zircon was completed in the scanning electron microscope room of Beijing Zirconium
Leading Technology Co., Ltd. The instrument used was an electronic JSM6510 (Japan) scanning electron microscope equipped with a Gantan cathode fluorescent probe.

Zircon U-Pb dating via LA-ICP-MS was completed at the State Key Laboratory of Deposit Geochemistry, Institute of Geochemistry, Chinese Academy of Sciences. The standard zircon 91500 was used as the external standard during the test; GJ-1 and Plešovice standard zircons were used as blind samples to test the U-Pb dating data quality. NIST SRM 610 was used as the external standard, and $\mathrm{Si}$ was used as the internal standard to mark the zircon. The $\mathrm{Pb}$ content was determined using $\mathrm{Zr}$ as the internal standard for other trace elements in zircon [50-51]. The original test data was processed offline using ICPMS DataCal software [51].

In situ micro-Zircon Hf isotope ratio testing was performed by the National Key Laboratory of Geological

Processes and Mineral Resources of the China University of Geosciences (Wuhan) using laser ablation multi-receiver cup plasma mass spectrometry (LA-MC-ICP-MS).

\section{Test Results}

\subsection{Mineragraphy}

The early mafic intrusion suite is mainly composed of long columnar or slab-like sericite and clay pseudomorphs of 
plagioclase, as well as quartz (pulse), calcite (pulse), and mica. The claying of the plagioclase coexists with the sericitization. When the two coexist with the feldspar, plagioclase is produced. In partially etched plagioclase, a polycrystalline twin structure can be observed. Intergrowths of quartz can be observed in the secondary structure. This polycrystalline twin crystal structure was observed in association with calcite, which was mostly pulsed with quartz, with a small amount produced in almond-shaped interstices. X-ray element mapping revealed some gold (Table 1).

The late mafic intrusion suite is mainly composed of plagioclase, pyroxene, hornblende, and biotite, with a small amount of magnetite. Observed structures include a gabbro structure, a diaphoric structure, a long inlaid crystal structure, as well as a Natuncurtain petrochemical, a green curtain petrochemical, a sericitization, some sericite, a sub-flash petrochemical, and a soap petrochemical. The plagioclase shows polysynthetic twins in a semi-self-shaped plate shape, with severe saussuritization and sericitization as well as serpentinization. Both clinopyroxene and orthopyroxene occur. The main eclipse is chloritization, and the pyroxene is second-rate hornblende in some of the edge, local hornblende. Few metal sulfides occur in the late mafic intrusion suite, in contrast to expectations from past studies. Metamorphic alteration was found to be too strong for a meaningful electron probe analysis, so no such analysis was performed.

\subsection{Zircon U-Pb Dating}

The zircon used for the analysis is shown in Table 2. The characteristics of magmatic zircon formation $(\mathrm{Th} / \mathrm{U}$ of magmatic zircon $>0.1$ ) are shown, the ordinary $\mathrm{Pb}$ content of zircon is low, and the zircon cathodoluminescence (CL) photograph is shown in Figure $4 a-b$. For the late mafic intrusion (FN), all the data corresponding to the harmonic conditions are plotted in Figure 4c-d. Except that the point FN-32 may be on the inherited zircon, the other points $206 \mathrm{~Pb} / 206 \mathrm{U}$ have a harmonic age of $219.9 \pm 6.6 \mathrm{Ma}$ (MSWD=1.2).

For the early mafic intrusion (ZSH-1), U-Pb isotope analysis was performed on 15 zircon particles with a $\mathrm{Th} / \mathrm{U}$ ratio between 0.38 and 1.00 . All the data matching the harmonic conditions were plotted in Figure 4. The U-Pb isotopic composition is harmonically within the error range. The weighted mean age of ${ }^{206} \mathrm{~Pb} /{ }^{238} \mathrm{U}$ is $258 \pm 5 \mathrm{Ma}$ (MSWD $=0.35$, 95\% confidence), which represents the crystallization age of the mafic intrusion.

Table 1. Electron probe data of early mafic intrusion' metal minerals - pyrite and arsenopyrite.

\begin{tabular}{|c|c|c|c|c|c|c|c|c|}
\hline Point number & As & Se & $\mathbf{Z n}$ & $\mathbf{N i}$ & $\mathbf{S}$ & Au & $\mathrm{Fe}$ & Total \\
\hline Apy-01 & 69.95 & 0 & 0 & 0.22 & 17.58 & 0.0916 & 12.05 & 99.89 \\
\hline Apy-02 & 70.39 & 0 & 0 & 0 & 17.16 & 0.1639 & 12.85 & 100.57 \\
\hline Apy-03 & 36.58 & 0 & 0.12 & 0 & 21.39 & 0 & 40.9 & 99 \\
\hline Apy-04 & 33.4 & 0 & 0 & 0 & 23.59 & 0.0905 & 42.06 & 99.14 \\
\hline Apy-05 & 35.65 & 0.07 & 0 & 0 & 22.35 & 0.0476 & 41.86 & 99.98 \\
\hline Apy-06 & 35.04 & 0 & 0 & 0.01 & 22.83 & 0.1 & 42.01 & 99.99 \\
\hline Apy-07 & 36.32 & 0 & 0 & 0.02 & 21.88 & 0.0277 & 41.2 & 99.46 \\
\hline Apy-08 & 34.42 & 0 & 0 & 0.05 & 22.51 & 0 & 42.78 & 99.76 \\
\hline Apy-09 & 41.3 & 0 & 0 & 0.03 & 22.5 & 0.036 & 34.44 & 98.29 \\
\hline Apy-10 & 41.89 & 0 & 0.33 & 0.01 & 21.46 & 0 & 36.15 & 99.83 \\
\hline Apy-11 & 40.93 & 0 & 0 & 0 & 22.57 & 0 & 34.19 & 97.69 \\
\hline Apy-12 & 44.21 & 0 & 0.17 & 0.03 & 21.54 & 0.042 & 33.88 & 99.87 \\
\hline Apy-13 & 40.59 & 0 & 0 & 0 & 22.6 & 0.037 & 34.64 & 97.87 \\
\hline Apy-14 & 41.85 & 0 & 0 & 0 & 22.66 & 0 & 34.4 & 98.91 \\
\hline Apy-15 & 39.89 & 0 & 0.01 & 0.09 & 21.88 & 0 & 34.66 & 96.54 \\
\hline Apy-16 & 68.41 & 0 & 3.31 & 0.14 & 17.28 & 2.1724 & 8.1 & 99.41 \\
\hline Apy-17 & 70.37 & 0 & 1.51 & 0 & 17.46 & 0 & 10 & 99.34 \\
\hline Apy-18 & 33.22 & 0 & 0.39 & 0 & 25.68 & 0 & 40.54 & 99.83 \\
\hline Py-1 & 7.97 & 0 & 0 & 0 & 61.17 & 0.4571 & 31.31 & 100.91 \\
\hline Py-2 & 2.24 & 0 & 0.2 & 0.01 & 47.31 & 0 & 49.61 & 99.37 \\
\hline Py-3 & 4.9 & 0 & 0.19 & 0 & 49.77 & 0 & 46.17 & 101.03 \\
\hline Py-4 & 4.32 & 0 & 0.3 & 0 & 52.03 & 0 & 46.48 & 103.13 \\
\hline Py-5 & 13.31 & 0 & 0 & 0.67 & 64.97 & 0.1227 & 20.8 & 99.88 \\
\hline Py-6 & 13.89 & 0 & 9.22 & 0.44 & 56.83 & 0.8889 & 16.5 & 97.78 \\
\hline Py-7 & 4.55 & 0 & 0.06 & 0 & 46.16 & 0.0329 & 49.24 & 100.04 \\
\hline Py-8 & 5.55 & 0 & 0.06 & 0.02 & 46.22 & 0 & 49.37 & 101.22 \\
\hline
\end{tabular}



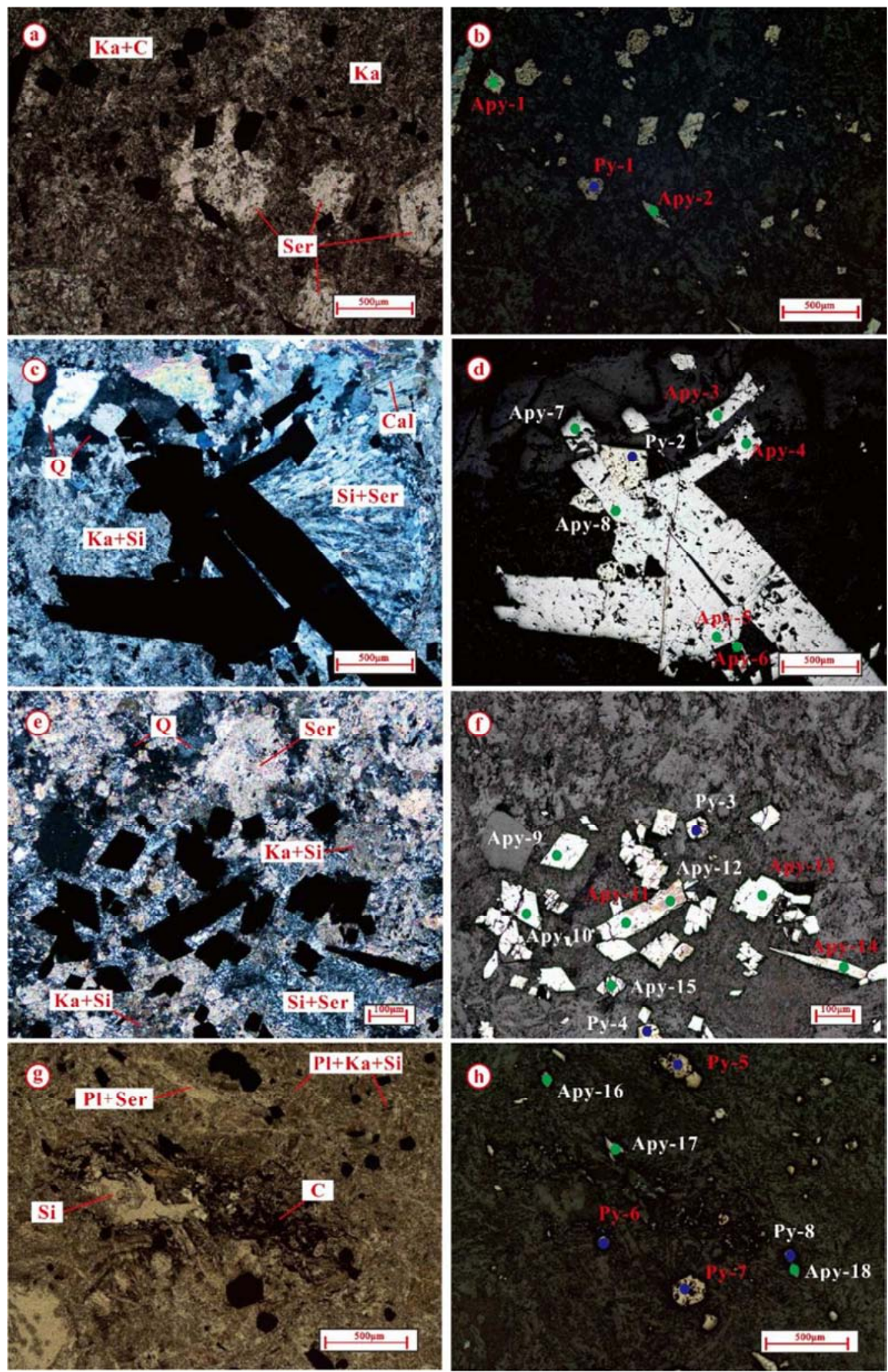

Figure 2. Early mafic intrusion ore and analysis point map.

Orthogonal polarized photo on the left; reflected light on the right. Attached to the position of the electronic probe point (the blue point is pyrite, the green point is a poisonous sand, and the red-pointed electronic probe point number is a gold-containing point). Pl-plagioclase, Ser-sericite, Py-pyrite, Apy-arsenopyrite, Cal-calcite, Ka-clay, C- carbonization.

a-b: The gold content was detected in the fine-grained diamond-like arsenopyrite and residual pyrite produced in the carbonized strong fine-grained arsenopyrite and almond-shaped sericite. C-d: the production of arsenopyrite and pyrite, and the strong silicidation zone. The coarse-grained arsenopyrite is interspersed with the medium pyrite. In the random electron probe position, no gold is found in the coarse-grained arsenopyrite and the medium-grained pyrite. E-f: The gold content was detected in the elongated diamond-shaped arsenopyrite. G-h: Gold is found in colloidal pyrite and arsenopyrite. 

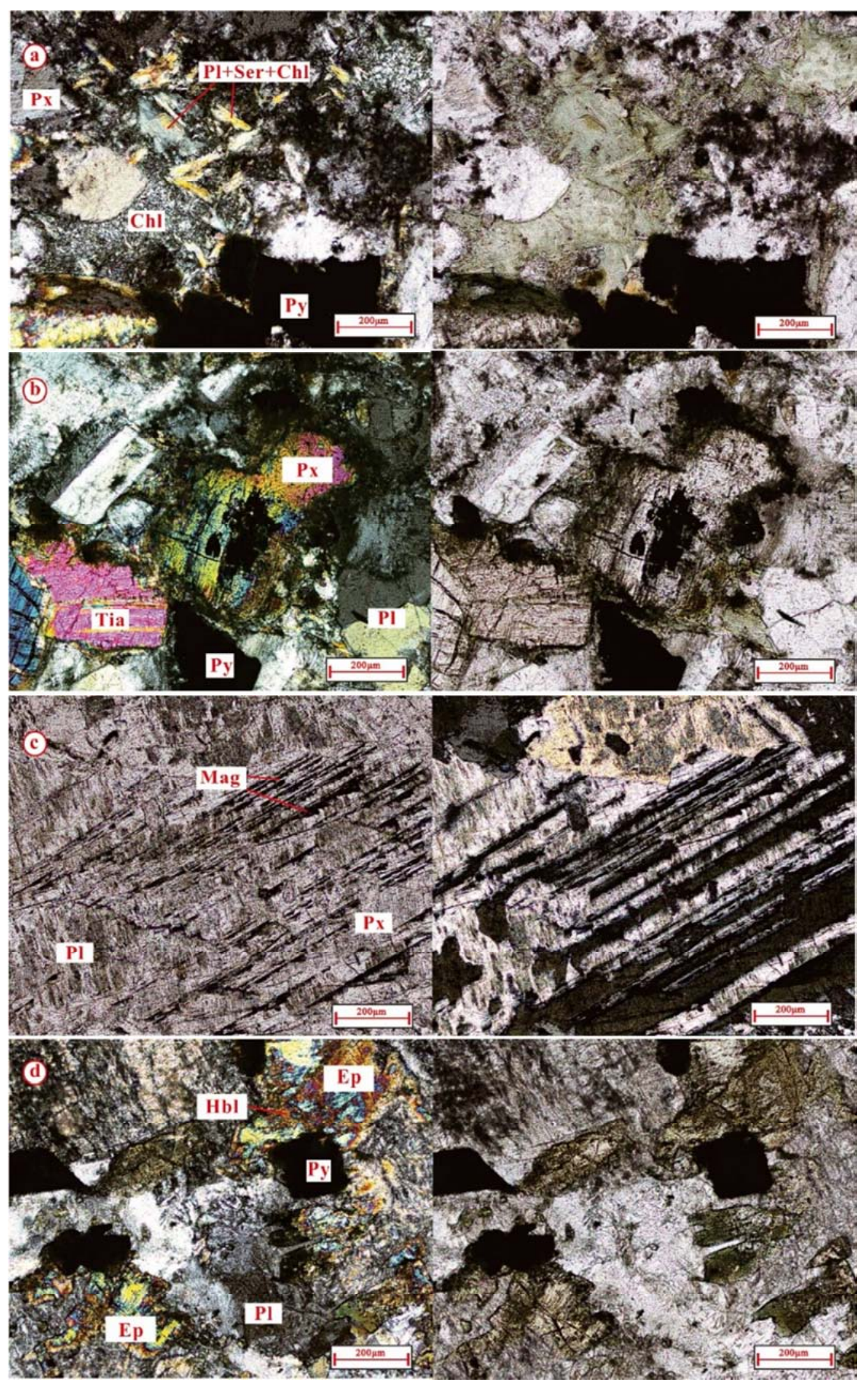

Figure 3. Late mafic intrusion mineral flakes.

Orthogonal polarization on the left side; single polarization on the right.

Pl- plagioclase, Px- pyroxene, Ser- sericite, Py- pyrite, Tia- titanium pyrite, Chl-chlorite, Hal- hornblende, Ep-epidotization.

a- plagioclaseis sericitization, chloritization, partially seen pyrite, -b-: pyroxene with reaction side, centeris argillation; c- magnetite in pyroxene; d- Hornblende epidotization. 
(a) FNL
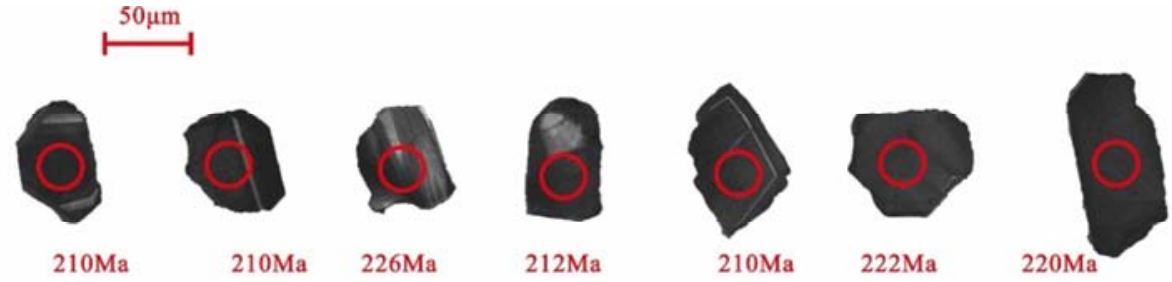

(b) FNE
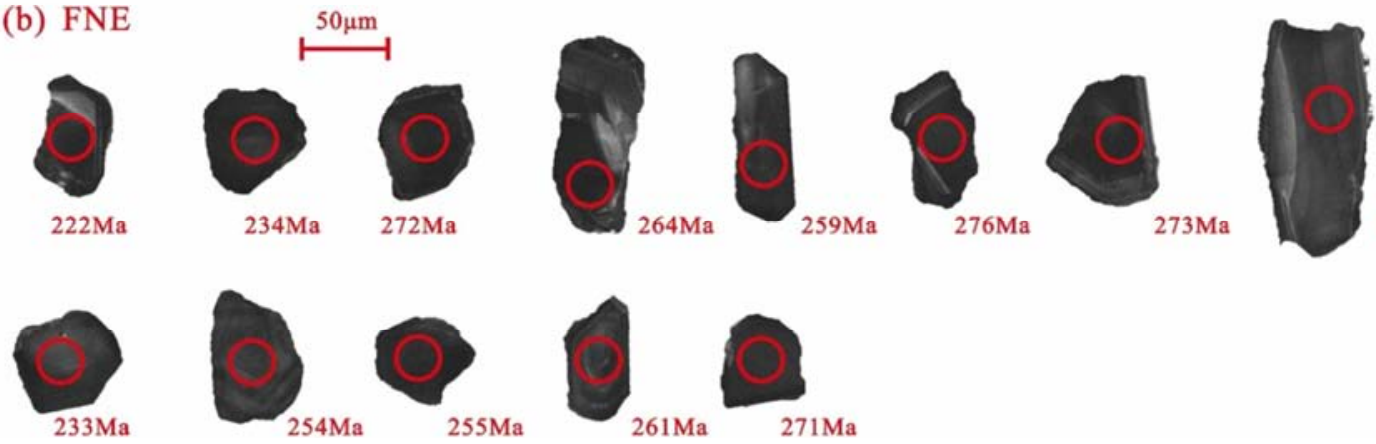

Figure 4. Representative zircon cathodoluminescence image of mafic intrusion in Funing area.
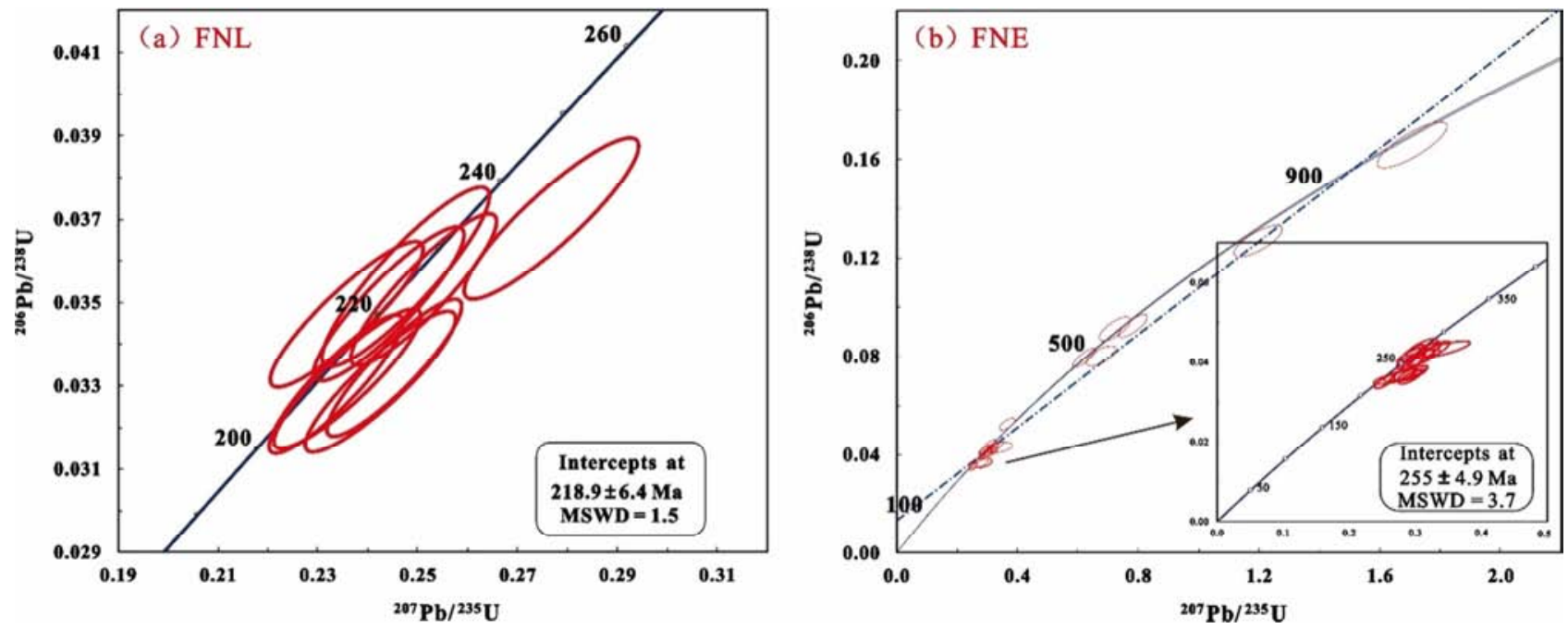

Figure 5. Age Harmonic Map of Representative Zircons from Two Phases of Basalt Rocks in Funing Area.

Table 2. LA-ICP-MS Data for the mafic intrusion of zircons from Funing.

\begin{tabular}{|c|c|c|c|c|c|c|c|c|c|}
\hline \multirow{2}{*}{ Sample no. } & \multicolumn{2}{|c|}{ Element (ppm) } & \multirow{2}{*}{$\mathbf{T h} / \mathbf{U}$} & \multicolumn{2}{|l|}{ Isotope ratio } & \multirow[b]{2}{*}{${ }^{207} \mathrm{~Pb} /{ }^{235} \mathrm{U}$} & \multirow[b]{2}{*}{$1 \sigma$} & \multirow[b]{2}{*}{${ }^{206} \mathrm{~Pb} /{ }^{238} \mathrm{U}$} & \multirow[b]{2}{*}{$1 \sigma$} \\
\hline & Th & $\mathbf{U}$ & & ${ }^{207} \mathrm{~Pb} /{ }^{206} \mathrm{~Pb}$ & $1 \sigma$ & & & & \\
\hline FNL-09 & 584 & 580 & 1.01 & 0.0507 & 0.0019 & 0.2512 & 0.0096 & 0.0353 & 0.0012 \\
\hline FNL-10 & 440 & 1007 & 0.44 & 0.0522 & 0.0021 & 0.2426 & 0.0099 & 0.0331 & 0.0011 \\
\hline FNL-16 & 85 & 148 & 0.58 & 0.0504 & 0.0018 & 0.2337 & 0.0088 & 0.0330 & 0.0011 \\
\hline FNL-20 & 85 & 215 & 0.40 & 0.0498 & 0.0019 & 0.2475 & 0.0111 & 0.0356 & 0.0014 \\
\hline FNL-21 & 265 & 401 & 0.66 & 0.0525 & 0.0019 & 0.2453 & 0.0089 & 0.0334 & 0.0011 \\
\hline FNL-26 & 283 & 375 & 0.75 & 0.0506 & 0.0020 & 0.2359 & 0.0097 & 0.0332 & 0.0011 \\
\hline FNL-30 & 91 & 255 & 0.36 & 0.0482 & 0.0020 & 0.2358 & 0.0101 & 0.0347 & 0.0011 \\
\hline FNL-25 & 352 & 597 & 0.59 & 0.0531 & 0.0021 & 0.2767 & 0.0115 & 0.0370 & 0.0013 \\
\hline FNE-01 & 178 & 289 & 0.62 & 0.0539 & 0.0044 & 0.2763 & 0.0258 & 0.0364 & 0.0013 \\
\hline FNE-03 & 1249 & 1572 & 0.79 & 0.0515 & 0.0020 & 0.2542 & 0.0099 & 0.0352 & 0.0011 \\
\hline FNE-04 & 173 & 310 & 0.56 & 0.0504 & 0.0024 & 0.3673 & 0.0175 & 0.0525 & 0.0017 \\
\hline FNE-08 & 936 & 1258 & 0.74 & 0.0517 & 0.0020 & 0.2543 & 0.0100 & 0.0351 & 0.0011 \\
\hline FNE-09 & 134 & 221 & 0.61 & 0.0562 & 0.0048 & 0.2854 & 0.0218 & 0.0370 & 0.0013 \\
\hline FNE-11 & 131 & 234 & 0.56 & 0.0575 & 0.0049 & 0.3399 & 0.0286 & 0.0432 & 0.0014 \\
\hline FNE-13 & 132 & 235 & 0.56 & 0.0518 & 0.0027 & 0.2955 & 0.0153 & 0.0418 & 0.0014 \\
\hline FNE-14 & 247 & 339 & 0.73 & 0.0564 & 0.0023 & 0.6202 & 0.0251 & 0.0793 & 0.0026 \\
\hline FNE-15 & 295 & 481 & 0.61 & 0.0544 & 0.0025 & 0.3081 & 0.0138 & 0.0411 & 0.0013 \\
\hline
\end{tabular}




\begin{tabular}{|c|c|c|c|c|c|c|c|c|c|}
\hline \multirow{2}{*}{ Sample no. } & \multicolumn{2}{|c|}{ Element (ppm) } & \multirow{2}{*}{$\mathbf{T h} / \mathbf{U}$} & \multirow{2}{*}{$\begin{array}{l}\text { Isotope ratio } \\
{ }^{207} \mathrm{~Pb} /{ }^{206} \mathrm{~Pb}\end{array}$} & \multirow[b]{2}{*}{$1 \sigma$} & \multirow[b]{2}{*}{${ }^{207} \mathrm{~Pb} /{ }^{235} \mathrm{U}$} & \multirow[b]{2}{*}{$1 \sigma$} & \multirow[b]{2}{*}{${ }^{206} \mathrm{~Pb} /{ }^{238} \mathrm{U}$} & \multirow[b]{2}{*}{$1 \sigma$} \\
\hline & Th & $\mathbf{U}$ & & & & & & & \\
\hline FNE-16 & 85 & 173 & 0.49 & 0.0737 & 0.0030 & 1.7072 & 0.0767 & 0.1659 & 0.0061 \\
\hline FNE-18 & 133 & 265 & 0.50 & 0.0515 & 0.0026 & 0.3099 & 0.0151 & 0.0438 & 0.0014 \\
\hline FNE-19 & 664 & 1245 & 0.53 & 0.0551 & 0.0021 & 0.3320 & 0.0131 & 0.0433 & 0.0014 \\
\hline FNE-20 & 134 & 134 & 1.00 & 0.0578 & 0.0028 & 0.7224 & 0.0345 & 0.0910 & 0.0032 \\
\hline FNE-21 & 51 & 157 & 0.32 & 0.0680 & 0.0029 & 1.1969 & 0.0518 & 0.1268 & 0.0041 \\
\hline FNE-23 & 150 & 113 & 1.33 & 0.0616 & 0.0031 & 0.6773 & 0.0339 & 0.0800 & 0.0027 \\
\hline FNE-24 & 301 & 568 & 0.53 & 0.0506 & 0.0022 & 0.2966 & 0.0128 & 0.0423 & 0.0014 \\
\hline FNE-25 & 144 & 304 & 0.47 & 0.0556 & 0.0028 & 0.2815 & 0.0139 & 0.0367 & 0.0012 \\
\hline FNE-26 & 5449 & 7432 & 0.73 & 0.0526 & 0.0019 & 0.2976 & 0.0118 & 0.0402 & 0.0013 \\
\hline FNE-28 & 579 & 1284 & 0.45 & 0.0514 & 0.0019 & 0.2875 & 0.0107 & 0.0403 & 0.0013 \\
\hline FNE-29 & 148 & 260 & 0.57 & 0.0553 & 0.0029 & 0.3127 & 0.0163 & 0.0413 & 0.0014 \\
\hline FNE-30 & 1563 & 1830 & 0.85 & 0.0539 & 0.0021 & 0.3200 & 0.0128 & 0.0430 & 0.0015 \\
\hline
\end{tabular}

Table 2. Continued.

\begin{tabular}{|c|c|c|c|c|c|c|c|c|c|}
\hline \multirow{2}{*}{ Sample no. } & \multicolumn{2}{|c|}{ Element (ppm) } & \multirow{2}{*}{$\mathbf{T h} / \mathbf{U}$} & \multicolumn{6}{|l|}{ Age (Ma) } \\
\hline & Th & $\mathbf{U}$ & & ${ }^{207} \mathrm{~Pb} /{ }^{206} \mathrm{~Pb}$ & $1 \sigma$ & ${ }^{207} \mathrm{~Pb} /{ }^{235} \mathrm{U}$ & $1 \sigma$ & ${ }^{206} \mathbf{P b} /{ }^{238} \mathrm{U}$ & $1 \sigma$ \\
\hline FNL-09 & 584 & 580 & 1.01 & 228 & 91.7 & 228 & 7.8 & 224 & 7.5 \\
\hline FNL-10 & 440 & 1007 & 0.44 & 295 & 86.1 & 221 & 8.1 & 210 & 6.9 \\
\hline FNL-16 & 85 & 148 & 0.58 & 213 & 83.3 & 213 & 7.3 & 210 & 6.8 \\
\hline FNL-20 & 85 & 215 & 0.40 & 183 & 119 & 225 & 9.0 & 226 & 8.9 \\
\hline FNL-21 & 265 & 401 & 0.66 & 309 & 76.8 & 223 & 7.3 & 212 & 6.7 \\
\hline FNL-26 & 283 & 375 & 0.75 & 233 & 97.2 & 215 & 8.0 & 210 & 6.9 \\
\hline FNL-29 & 4765 & 6220 & 0.77 & 187 & 92.6 & 222 & 8.1 & 222 & 7.6 \\
\hline FNL-30 & 91 & 255 & 0.36 & 109 & 98.1 & 215 & 8.3 & 220 & 7.1 \\
\hline FNL-25 & 352 & 597 & 0.59 & 332 & 90.7 & 248 & 9.2 & 234 & 7.9 \\
\hline FNE-01 & 178 & 289 & 0.62 & 369 & 187.0 & 248 & 20.5 & 230 & 7.8 \\
\hline FNE-03 & 1249 & 1572 & 0.79 & 261 & 87.0 & 230 & 8.0 & 223 & 7.1 \\
\hline FNE-04 & 173 & 310 & 0.56 & 213 & 112.9 & 318 & 13.0 & 330 & 10.7 \\
\hline FNE-08 & 936 & 1258 & 0.74 & 333 & 88.9 & 230 & 8.1 & 222 & 7.1 \\
\hline FNE-09 & 134 & 221 & 0.61 & 461 & 190.7 & 255 & 17.2 & 234 & 7.8 \\
\hline FNE-10 & 120 & 235 & 0.51 & 643 & 92.6 & 587 & 18.5 & 569 & 17.8 \\
\hline FNE-11 & 131 & 234 & 0.56 & 509 & 188.9 & 297 & 21.7 & 272 & 8.8 \\
\hline FNE-13 & 132 & 235 & 0.56 & 280 & 120.4 & 263 & 12.0 & 264 & 8.7 \\
\hline FNE-14 & 247 & 339 & 0.73 & 478 & 82.4 & 490 & 15.7 & 492 & 15.7 \\
\hline FNE-15 & 295 & 481 & 0.61 & 387 & 101.8 & 273 & 10.7 & 259 & 8.3 \\
\hline FNE-16 & 85 & 173 & 0.49 & 1033 & 86.1 & 1011 & 28.8 & 990 & 33.5 \\
\hline FNE-18 & 133 & 265 & 0.50 & 261 & 118.5 & 274 & 11.7 & 276 & 8.9 \\
\hline FNE-19 & 664 & 1245 & 0.53 & 417 & 85.2 & 291 & 10.0 & 273 & 8.6 \\
\hline FNE-20 & 134 & 134 & 1.00 & 520 & 110.2 & 552 & 20.4 & 561 & 18.6 \\
\hline FNE-21 & 51 & 157 & 0.32 & 878 & 88.6 & 799 & 24.0 & 770 & 23.7 \\
\hline FNE-23 & 150 & 113 & 1.33 & 661 & 106.3 & 525 & 20.5 & 496 & 16.2 \\
\hline FNE-24 & 301 & 568 & 0.53 & 233 & 100.0 & 264 & 10.0 & 267 & 8.8 \\
\hline FNE-25 & 144 & 304 & 0.47 & 439 & 113.0 & 252 & 11.0 & 233 & 7.6 \\
\hline FNE-26 & 5449 & 7432 & 0.73 & 322 & 79.6 & 265 & 9.2 & 254 & 8.2 \\
\hline FNE-28 & 579 & 1284 & 0.45 & 257 & 87.0 & 257 & 8.4 & 255 & 7.8 \\
\hline FNE-29 & 148 & 260 & 0.57 & 433 & 116.7 & 276 & 12.6 & 261 & 8.8 \\
\hline FNE-30 & 1563 & 1830 & 0.85 & 365 & 87.0 & 282 & 9.8 & 271 & 9.1 \\
\hline
\end{tabular}

\section{Discussion}

In the late Middle Triassic, the intrusion of magma provided conditions for the activation and migration of ore-forming materials, enabling ore-forming hydrothermal fluid to pass through deep, large faults, migrate from high-pressure regions, and precipitate in the low-pressure fracture zone. The ore-rich part has its origins in superimposed mineralization during subsequent tectonic movement $[30,52]$. Hydrothermal alteration of the surrounding rock manifests as chlorite, sericite, serpentine, skarn, etc. Such hydrothermal alteration is the source of melt-hydrothermal sulfide deposits, skarn-type titano-magnetite deposits, Carlin-type gold deposits, etc. [15,

\section{$40,53,54]$.}

In Funing, volcanic rocks and materials, especially basic volcanic rocks, host several important gold occurrences [55]. The $\mathrm{Zn}, \mathrm{Cu}, \mathrm{Cr}, \mathrm{Ni}$, and $\mathrm{V}$ contents in local basalt and clastic rocks containing volcanic materials are much higher than in other local rock types. This observation illustrates a potential relationship between metallicity and basic volcanic materials [56-57].

In this study, the crystallization age for the Funing area's early mafic intrusion suite was found to be $255 \pm 4.9$ Ma. Previous studies have shown that the Funing's early mafic intrusion suite is related to the Emeishan mantle plume. The $\mathrm{Hf}$ isotope ratio indicate a source of inherited zircons derived from the formation, which is also consistent with the dating 
results. The Zircon U-Pb date for Funing's late mafic intrusion suite indicates a crystallization age of $218.9 \pm 6.4 \mathrm{Ma}$, related in time to plate subduction [58]. The main trace elements and Hf isotopes support this view. This emplacement age is consistent with the age of the Sang gold deposits measured by the hydrothermal rutile $\mathrm{U}-\mathrm{Pb}$ method [59].

For the Zheshang Gold Mine and the Laozhaiwan Gold Mine in the Funing area, diabase is the main ore-bearing lithology. According to the latest sericite Ar-Ar dating, the crystallization age of the Zheshang deposit is determined to be $215.3 \pm 1.9 \mathrm{Ma}$ [14]. Meanwhile, the crystallization age of the Laozhaiwan gold deposit is determined to be $218 \pm 18 \mathrm{Ma}$ based on monazite $\mathrm{U}-\mathrm{Pb}$ dating. The mafic intrusion hosting the Zheshang gold deposit are mainly the early mafic intrusion suite of the Indosinian tectonic period $[10,57,60]$, with a notable gap in time between the early mafic intrusion suite's age and that of the gold deposit. The $\mathrm{H}$ and $\mathrm{O}$ isotopic compositions of the mineral inclusions in the Zheshang Gold Mine indicate that the ore-forming fluids are sourced mainly from atmospheric precipitation and strata [47]. This evidence is based on time and material sources, indicating that the ore-forming fluid is not directly related to early magmatism in the area. However, in this study, pyrite and arsenopyrite, which are Au-bearing minerals, were found in the early mafic intrusion of the Sang area (Figure 2). The ore-forming fluid of the Zheshang Gold deposit is inferred to have mainly been weakly acidic. This weakly acidic, Au-bearing hydrothermal fluid can dissolve Ti-Fe-containing pyroxene or ilmenite in the ore-bearing diabase to release $\mathrm{Fe} 2+$, which is then available for the formation of sulfides and precipitation of $\mathrm{Au}$. The vulcanization process of dissolved $\mathrm{Fe}$ enriches the Au-bearing pyrite and arsenopyrite [61] while retaining the original crystal morphology of Ti-Fe-containing minerals. This vulcanization is accompanied by hydrothermal alterations such as chloritization and sericitization (Figure 2). This suggests that for the Zheshang Gold Mine, the early mafic intrusion in the area are likely to have exchanged material with ore-forming fluids formed from atmospheric precipitation or building water. At the same time, it was shown that the ore-forming fluids of the Laozhaiwan gold deposit were also weakly acidic, while the sulfur isotope composition is higher than that of mantle $\mathrm{S}$ or of deep-sourced magmatic-related sulfides [15]. The deep sulfur or magma sulfur source associated with the intrusion of diabase veins participates in mineralization and is mixed with sedimentary sulfur [15, 62-64], promoting the enrichment of $\mathrm{Au}$ in pyrite and arsenopyrite. This Au precipitation mechanism is similar to that of another Carlin-type gold deposit in the region, the $232 \pm 5$ Ma Ana Gold Mine [61]. However, due to structural constraints, the early mafic intrusion hosting the Zheshang Gold Mine did not mineralize quite as strongly.

Through the study of these representative deposits, we propose that the ore-forming fluid (hydrothermal fluid) in this area was composed of magmatic water (or another fluid dissimilar to the upper-mantle fluid) from a deep source. During the ascent through the deep fault system, the source fluid is inevitably mixed. When the source fluid reaches shallow depths, it inevitably mixes with some atmospheric precipitation and surface water, and the sourcing of ore-forming fluids becomes complex. However, ore at all depths is closely related to magmatic hydrothermal fluid.

In contrast to the early mafic intrusion suite, the $218.9 \pm 6.4-\mathrm{Ma}$ late mafic intrusion suite is similar in age to those of several Carlin-type gold deposits in the area (Table 3). This age is contemporaneous with the formation of deep granite granules formed by depressurization melting during the Indosinian collisional extension as well as with their associated hydrothermal tungsten-tin deposits in the surrounding area afterward [65-66]. Although the medium-acid rock mass exposed at large scale on the surface has not been encountered in the Hualin Karin-type gold mining area, geophysical research indicates that there are several hidden granite belts in the "Golden Triangle" area of the Guizhou-Yunnan-Guangxi region, with the distribution of the granite belt being basically the same as that of the gold belt in the area.

Therefore, it is easier to transfer ore-forming fluids from the tectonic late mafic intrusion suite, and re-activate the migration of ore-forming materials enriched by the early mafic intrusion suite. The alteration of the late mafic intrusion suite also indicates a certain degree of material exchange with the surrounding rock (Figure 3). The final result is the coincident spatial relationship between the late mafic intrusion suite and the various types of deposits in the area, notably in the contact zone with two-stage mafic intrusion. However, due to the compression of the early mafic intrusion suite, the late mafic intrusion suite was not exposed on a large scale in the Funing area. Through this research, we suggest that if there is a concealed granite mass, its real significance is to supplement this area's dynamics and thermal driving mechanisms of mineralization in time and space. In addition to providing thermal driving force, the mafic intrusion also provides metallogenic space and even a small amount of ore-forming material, although the water in the ore-forming fluid is mainly atmospheric caustic groundwater. At this stage, the granite body does not provide mineralization, but is still a thermal driving force. Of course, study of hidden granites in this area may lead to more accurate conclusions. Such a granite, although derived dynamically from various mafic intrusion, provides the thermal driving force for the formation of gold deposits. Meanwhile, the mafic intrusion contribute more in terms of material sources and metallogenic spaces to the formation and development of gold deposits.

Previous studies have shown that the Youjiang Basin has experienced two stages of metallogenic events, mainly in the Indosinian and Yanshanian periods [67-69]. However, this study believes that the gold deposits in the Funing area are mainly Indosinian mineralization, which is closely related to the late mafic intrusion in the area. During the Indosinian period, the main framework of the gold deposits in the Jingui Golden Triangle was established. The mineralization of the Yanshanian period may be closely related to the deep granite activity of the Jurassic. The mineralization of the Yanshanian period is superimposed on the ore deposit area of the Youjiang 
Basin, which mainly forms deposits such as strontium, mercury and arsenic [65, 69-70] which is similar to the mineralization mechanism of the Indosinian period. According to the existing gold deposit research, the gold deposits in the Funing area show a close relationship with the
Indosinian mafic intrusion, and the precipitation of gold is related to the two-stage mafic intrusion. Due to the acquired space-time advantages of late-stage mafic intrusion, it is the decisive force for large-scale gold mineralization, so it can be used as an indicator for finding large mines in Funing area.

Table 3. Age of gold deposits.

\begin{tabular}{|c|c|c|c|c|c|c|c|}
\hline \multicolumn{2}{|c|}{ No. Deposit } & \multirow{2}{*}{$\begin{array}{l}\text { Type } \\
\text { Carlin-type }\end{array}$} & \multirow[t]{2}{*}{ Area } & \multirow{2}{*}{$\begin{array}{l}\text { Host rock } \\
\text { Late Permian Decarbonization, } \\
\text { silicification, dolomitization }\end{array}$} & \multirow{2}{*}{$\begin{array}{l}\begin{array}{l}\text { Mineralization } \\
\text { age (Ma) }\end{array} \\
235 \pm 33\end{array}$} & \multirow{2}{*}{$\begin{array}{l}\text { Minera/and method } \\
\text { Arsenopyrite, Re-Os }\end{array}$} & \multirow{2}{*}{$\begin{array}{l}\text { Reference } \\
\text { (Chen et al.,) [71] }\end{array}$} \\
\hline 1 & Shuiyindong & & & & & & \\
\hline \multirow{2}{*}{2} & \multirow{2}{*}{ Lannigou } & \multirow{2}{*}{ Carlin-type } & \multirow{5}{*}{$\begin{array}{l}\text { Yunnan- } \\
\text { Guizhou } \\
- \\
\text { Guangxi } \\
\text { area }\end{array}$} & \multirow{3}{*}{$\begin{array}{l}\text { Middle Triassic Silicification, } \\
\text { carbonatization argillization } \\
\text { Middle Triassic Decarbonization, } \\
\text { silicification, argillization }\end{array}$} & $194.6 \pm 2$ & Sericite, Ar-Ar & (Chen et al.,) [72] \\
\hline & & & & & $204 \pm 19$ & Arsenopyrite, Re-Os & (Chen et al.,) [71] \\
\hline 3 & Jinya & Carlin-type & & & $206 \pm 22$ & Arsenopyrite, $\mathrm{Re}-\mathrm{Os}$ & (Chen et al.,) [71] \\
\hline \multirow{2}{*}{4} & \multirow{2}{*}{ Zhesang } & \multirow{2}{*}{ Carlin-type } & & \multirow{2}{*}{$\begin{array}{l}\text { Permian calcareous clastic } \\
\text { sedimentary rocks }\end{array}$} & $215.3 \pm 1.9$ & Sericite, Ar-Ar & (Pi et al.,) [14] \\
\hline & & & & & $213.6 \pm 4.6$ & Rutile, U-Pb & (Pi et al.,) [59] \\
\hline \multirow{2}{*}{5} & \multirow{2}{*}{ Laozhaiwan } & \multirow{2}{*}{ Carlin-type } & & \multirow{2}{*}{$\begin{array}{l}\text { Early Devonian Silicification, } \\
\text { carbonatization, sericitization }\end{array}$} & $218 \pm 18$ & Monazite, U-Pb & To be published \\
\hline & & & & & $230 \pm 11$ & Monazite, U-Pb & To be published \\
\hline
\end{tabular}

\section{Conclusion}

Two mafic intrusions are distributed in the Funing area. Through petrological mineralogy, and zircon $\mathrm{U}-\mathrm{Pb}$ dating, the following understandings have been obtained as follows:

(1) The crystallization age of the early mafic intrusions was measured. The U-Pb age of the early mafic intrusionss was $255 \pm 4.9 \mathrm{Ma}$, which was consistent with the previous research results. It is believed that the early mafic intrusionss of Funing are related to the Emeishan mantle plume. The late mafic intrusions $206 \mathrm{~Pb} / 238 \mathrm{U}$ is $218.9 \pm 6.4 \mathrm{Ma}(\mathrm{MSWD}=1.5)$, and the plate subduction is closely related. The zircon Hf isotope also supports this view. The metallogenic time of several Carlin-type gold deposits in the late-mafic intrusions and Funing area is consistent within the error range.

(2) There are close links between the two mafic intrusions and the gold deposits in the Funing area. Combined with mineralogy studies, it is believed that early mafic intrusionss may limied contribute to the early enrichment of $\mathrm{Au}$ through the action of water-rock, together with atmospheric precipitation and stratigraphic water. The late mafic intrusionss are more favorable for mineralization due to the tectonic setting of the post-initiation collision and extension at Indosinian period. Finally, Au precipitated with favorable latent rocks in the favorable part of the structure, forming several large gold deposits in the area. Therefore, the late mafic intrusions can be used as a marker for further prospecting in the area.

\section{Acknowledgements}

The selection of zircon granules was completed in Langfang Chengxin Geological Services Co., Ltd. The cathodoluminescence image of zircon was completed in the scanning electron microscope room of Beijing Zirconium Leading Technology Co., Ltd. Chen Hongyi, the electronic probe room of Guilin University of Technology, provided convenience for this work. Isotopic dating has been assisted by the Laser Plasma Mass Spectrometry Laboratory of the State Key Laboratory of Deposit Geochemistry, Institute of Geochemistry, Chinese Academy of Sciences. I would like to express my gratitude her.

\section{References}

[1]. McNeil, A. M., Kerrich, R. Archean lamprophyre dykes and gold mineralization, Matheson, Ontario: the conjunction of LILE-enriched mafic magmas, deep crustal structures, and $\mathrm{Au}$ concentration. Canadian Journal of Earth Sciences. 1986, 23: 324-343.

[2]. Tu, G. Z. Two Unique Mineralization Areas in Southwest China. Bulletin of Mineralogy Petrology and Geochemistry. 2002, 21: 1-2.

[3]. Chen, Y. H., Yao, S. Z., Pan, Y. M. Geochemistry of lamprophyres at the Daping gold deposit, Yunnan Province, China: Constraints on the timing of gold mineralization and evidence for mantle convection in the eastern Tibetan Plateau. Journal of Asian Earth Sciences. 2014, 93: 129-145.

[4]. Gan, T., Huang, Z. L. Platinum-group element and Re-Os geochemistry of lamprophyres in the Zhenyuan gold deposit, Yunnan Province, China: Implications for petrogenesis and mantle evolution. Lithos. 2017, 282: 228-239.

[5]. Lanjewa, S., Randiv, K. Lamprophyres from the Harohalli dyke swarm in the Halaguru and Mysore areas, Southern India: Implications for backarc basin magmatism. Journal of Asian Earth Sciences. 2018, 157: 329-347.

[6]. Groves, D. I., Goldfarb, R. J, Gebre-Mariam, M., Hagemann, S G., Robert, F. Orogenic gold deposits: A proposed classification in the context of their crustal distribution and relationship to other gold deposit types. Ore Geology Reviews. 1998, 13: 7-27.

[7]. Yan, Y. T., Zhang, N., Li, S. R, Li, Y. S. Mineral chemistry and isotope geochemistry of pyrite from the Heilangou gold deposit, Jiaodong Peninsula, Eastern China. Geoscience Frontiers. 2014, 5: 205-213. 
[8]. Kovalev, K. R., Kuzmina, O. N., Dyachkov, B. A., Vladimirov, A. G., Kalinin, Y. A., Naumov, E. A., Kirillov, M. V., Annikova, I. Y. Disseminated gold-sulfide mineralization at the Zhaima deposit, eastern Kazakhstan. Geology of Ore Deposits. 2016, 58: 116-133.

[9]. Wenchao, S., Keyou, Y., Ruizhong, H., Feng, C. Fluid inclusion chronological study of the carlin-type gold deposits in southwestern china: As exemplified by the lannigou gold deposit, guizhou province. Acta mineralogica sinica. 1998, 18: 359-362.

[10]. Bao-cheng, P., Chang-song, L., Xian-rong, L., Chao-yong, H., Xin-guo, Z. The characteristic and origin of ore-forming fliud from micro-disseminated gold deposits in youjiang basin. Geology and Prospecting. 2005, 41: 13-17.

[11]. Ressel, M. W., Henry, C. D. Igneous geology of the Carlin trend, Nevada: Development of the eocene plutonic complex and significance for Carlin-type gold deposits. Economic Geology. 2006, 101: 347-383.

[12]. Chen, M., Zhang, Z., Santosh, M., Dang, Y., Zhang, W. The Carlin-type gold deposits of the "golden triangle" of SW China: $\mathrm{Pb}$ and $\mathrm{S}$ isotopic constraints for the ore genesis. Journal of Asian Earth Sciences. 2015b, 103: 115-128.

[13]. Chen, Y., Chen, B. Geological-geochemical features and genesis of ShuiyindongCarlin gold deposit in southwestern Guizhou Province. Geological survey of china. 2016, 3: 10-14 (in Chinese).

[14]. Pi, Q., Hu, R., Peng, K., Wu, J., Wei, C., Huang, Y. Geochronology of the Zhesang gold deposit and maficrock in Funing County of Yunnan Province, with special reference to the dynamic background of Carlin-type gold deposits inthe Dian-Qian-Gui region. Acta Petrologica Sinica. 2016a, 32: 3331-3342.

[15]. Zhang, J., Su, Q., Liu, X., He, Z., Zhou, Y., Li, Z., Zhao, K. Characteristics of geology and isotopic geochemistryof the Laozhaiwan gold deposit in southeastern Yunnan Province, China. Acta Petrologica Sinica. 2014, 30: 2657-2668.

[16]. Jianzhong, F., Dongbo, W., Xueming, W., Yishan, Z., Tiefeng, L. Magmatic Gold Mineralization in the Western Qinling Orogenic Belt: Geology and Metallogenesis of the Baguamiao, Liba and Xiaogouli Gold Deposits. Acta Geologica Sinica English Edition, 2004, 529-533.

[17]. He, H., Wei, L., Zhang, S., Gao, Y., Xu, Y. Helium, Argon, Hydrogen and Oxygen isotopic characters of ore-forming fluid of Baguamiao gold deposit inS haanxi province. Gold. 2007, 30: 3 .

[18]. Jingwen, M., Yanhe, L., Hongyan, L. Helium isotopic evidence on metalgenisis of mantle fluids in the wangu gold deposit, hun an province. Geological Review. 1997, 43: 646-649 (in Chinese).

[19]. Zhilin, W., Teng, D., Guojun, D., Fenghui, Z., Deru, X., Zhilin, W., Ge, L., Genwen, C. Characteristics of Ore-controlling Structures of Wangu Gold Deposit in Northeastern Hunan Province. Geotectonica et Metallogenia. 2016, 40: 281-294.

[20]. Jia, D., Hu, R. Analysis of Genesis of Carlin_type Gold Deposits in Yunnan Guizhou Guangxi Triangle Area. Mineral Deposits. 2011, 20: 378-384 (in Chinese).

[21]. Yuguo Z, Jishun L, Zuohua, W., Yufei, O., Qizhi, G., Deli, L., Yuanyou, H. The sources of ore-forming substance of
Carlin-type gold deposit: A discussion based on the characteristics of regional stratigraphic geochemical evolution in "Gold-Triangle" area of Yunnan, Guizhou, Guangxi Provinces. Earth Science Frontiers. 2009, 16: 199-208.

[22]. Bierlein, F. P., Arne, D. C., McKnight, S., Lu, J., Reeves, S., Besanko, J., Marek, J., Cooke, D. Wall-rock petrology and geochemistry in alteration halos associated with mesothermal gold mineralization, central Victoria, Australia. Economic Geology And the Bulletin Of the Society Of Economic Geologists. 2000, 95: 283-311.

[23]. Zhai, M. G., Santosh, M. Metallogeny of the North China Craton: Link with secular changes in the evolving Earth. Gondwana Research. 2013, 24: 275-297.

[24]. Li, L., Li, S. R., Santosh, M., Li, Q., Gu, Y., Lu, W. J., Zhang, H. F., Shen, J. F., Zhao, G. C. Dyke swarms and their role in the genesis of world-class gold deposits: Insights from the Jiaodong peninsula, China. Journal of Asian Earth Sciences. 2016, 130: 2-22.

[25]. Xu, J. P., Jia, J. F., Fang, Y. C. Geological characteristics and prospecting criteria of Zhesang gold deposit in Funing county, Yunnan. Prospecting technology. 2018, 13: 085-087.

[26]. Nie, F., Jiang, S., Hou, W., Liu, Y., Xiao, W. Geological features and genesis of gold deposits hosted by low-grade metamorphic rocks in central-western Inner Mongolia. Kuang chuang di zhi=Mineral deposits. 2010, 58-70. (in Chinese).

[27]. Zhao, H. X., Frimmel, H. E., Jiang, S. Y., Dai, B. Z. LA-ICP-MS trace element analysis of pyrite from the Xiaoqinling gold district, China: Implications for ore genesis. Ore Geology Reviews. 2011, 43: 142-153.

[28]. Zhu, R. X., Fan, H. R., Li, J. W., Meng, Q. R., Li, S. R., Zeng, Q. D. Decratonic gold deposits. Science China-Earth Sciences. 2015, 58: 1523-1537.

[29]. Shao, Y. 1: 20 million Funing area regional geological research report. 1978a.

[30]. Yncun, W., Xiaobing, Z., Hui, Q. The classification and the representativedeposit of micro disseminated audeposit of guangnan - funing. Yunnan Geology. 2013, 32: 259-263.

[31]. Henglin, L., Xijun, L., Jifeng, X., Zhiqiang, K., Yu, S., Wenlong, H., Xuefeng, C., Weinan, W., Qiongdan, L., Ye, Y. Geochemical evolution characteristics and regional tectonic significance of mafic rocks from Youjiang Basin. Journal of Guilin University of Technology. 2015, 35: 1674-9057 (in Chinese).

[32]. Wang, Z., Wu, H., Kuang, G. Haracteristics of the late paleozoic oceanic basalts andtheir eruptive environments in west guangxi. Acta petrologica sinica. 1997, 13: 135-140.

[33]. Wu, G., Wu, H., Zhong, D., Kuang, G., Ji, J. Volcanic rocks of paleotethyan oceanic island and island-arc bordering yunnan and guangxi, china. Geoscience. 2000, 14: 8.

[34]. Hou, Q., Fu, B., Kang, Y. Tectonic features of magmatic rocks in the southern part of the Youjiang Basin, Guangxi South China Youth Geoseience Symposium. 2003, pp 33-37 (in Chinese).

[35]. Qiu, Y., Zhang, B. On eastern extension of the paleo-Tethys in South China. Regional geology of China. 2000, 19: 175-180. 
[36]. Cai, J. X., Zhang, K. J. A new model for the Indochina and South China collision during the Late Permian to the Middle Triassic. Tectonophysics. 2009, 467, 35-43.

[37]. Zhang, J., Jiang, T. Sedimentary characteristics of triassic back-arc basiv of youjiang and its revolution. Guangxi geology. 1994, 7: 1-14

[38]. Wei, X., Yuping, L., Li, G., Lin, Y., Daohui, P., Zhen, L. Geochemistry and tectonic setting of the babu ophiolite, southeast yunnan. Acta Mineralogica Sinica. 2008, 28: 6-14.

[39]. Fang, W., Zhang, H., Jia, R. Dynamics of Triassic Back-Arc Rift Basin and its MetallogenicSequence in Gejiu of Yunnan Province to Napo of Guangxi Zhuang Autonomous Region, China. Geotectonica et Metallogenia. 2011, 35: 15.

[40]. Xiaofeng, Q., Zongqi, W., Yingli, Z., Luozhong, P., Guiang, H., Fusheng, Z. Geochemistry of Permian Mafic Igneous Rocks from the Napo-Qinzhou Tectonic Belt in Southwest Guangxi, Southwest China: Implications for Arc-Back Arc Basin Magmatic Evolution. Acta Geologica Sinica - English Edition. 2012, 86: 1182-1199.

[41]. Goldfarb, R. J., Santosh, M. The dilemma of the Jiaodong gold deposits: Are they unique? Geoscience Frontiers. 2014, 5: 139-153.

[42]. Fan, W., Wang, Y., Peng, T., Miao, L., Guo, F. Ar-Ar and U-Pb geochronology of Late Paleozoic basalts in western Guangxi and their constraints on the eruption era of Emeishan basalt province. Chinese Science Bulletin. 2004, 49: 9 (in Chinese).

[43]. Liao, S., Liu, X., Shi, Y., Huang, W., Guo, L. Products of interaction between mantle plume and island arc magma: evidence from mafic intrusion in the diabase type gold deposit in western Guangxi. Acta Mineralogica Sinica. 2013, 33: 111-113 (in Chinese).

[44]. Yang, J. H., Cawood, P. A., Du, Y. S., Huang, H., Hu, L. S. Detrital record of Indosinian mountain building in SW China: Provenance of the Middle Triassic turbidites in the Youjiang Basin. Tectonophysics. 2012, 574: 105-117.

[45]. Bo, S., Quanren, Y., Zhongjin, X., Huiming, C., Tieqiu, M., Guangyuan, Y. Sedimentary Characteristics and Tectonic Setting of the Middle Triassic Pingxiang Basin, Guangxi. Acta Geologica Sinica. 2013, 97: 453-473.

[46]. Zhuhuan, S., Yunbao, Y. Preliminary Study on Finding Deposit of Micro-Grain Type Gold Deposits in Southeast Yunnan. West-China Exploration Engineering. 2007, 133: 65-68.

[47]. Hongzhang, D., Cuihua, C., Xuexiang, G., Baohua, L., Shuyi, D., Wenbin, C. Characteristics of Ore-forming Fluids from Zhesang Gold Deposit in Funing County, Yunnan Province. Geoscience. 2014, 28: 893-904 (in Chinese).

[48]. Hongzhang, D., Cuihua, C., Jiajun, Y., Chaoxin, H. Elemental Geochemical Characteristics of the Zhesang Gold Deposit in the Yunnan Province and Their Geological Significance. Bulletin of mineralogy, and petrology and geochemistry. 2015, 34: 11 .

[49]. Shao, Y. 1: 200000 FuNing's mineral map. 1978b.

[50]. Li, J., Liang, X., Dong Y., Tu, X., Xu, J. Precise Measurement reconcentration of natural rock sample by MC-ICPMS using iridium to correct for mass fractionation. Geochimica. 2007, 36: 153-160 (in Chinese).
[51]. Xie, J., Yang, X., Du, J., Sun, W. Zircon U-Pb geochronology of the Mesozoicintrusive rocks in the Tongling reigon: ImPlicaitons for copper-gold mineralizaiton. Acta Petrologica Sinica. 2008, 24: 1782-1800.

[52]. Wenlong, Z., Bo, L., Qing, H., Liu, M. Disscussion on Mineralization Characteristics and Genesis of $\mathrm{Cu}-\mathrm{Ni}$ Sulfide Deposits of Weidong in Funing mafic intrusion Area. Science Technology and Engineering. 2013, 13: 5908-5914.

[53]. Chen, G., Yang, B. Fractal features of spatial distribution of gold deposits in dian-qian-gui region. Contributions to geology and mineral resouces research. 1996, 11: 44-50 (in Chinese).

[54]. JianQiang, Z. Ore characteristics and modes of occurrence of gold in the Zhesang gold deposit, Yunnan. Geology and Mineral Resources of South China. 2014, 30: 383-388.

[55]. Nengxue, S., Xujun, L., Shupeng, Z. The metallogenetic enrichment rule of weilin au deposit, funing. Yunnan Geology. 2011, 30: 134-137.

[56]. Guo, J. Mineralizing Process of Micrograin-type Gold Deposits in Southeastern Yunnan and Northwestern Guangxi. Mineral Deposits. 2004, 21: 4.

[57]. Liu, J., Ye, J., Liu, J., Xuexiang, G. Relationship Between Sediments hosted Micro_disseminated GoldDeposits and Basin Evolution: Case Study in Youjiang Basin, South China. Mineral Deposits. 2001, 20: 11.

[58]. Zhou, M. F., Zhao, J. H., Qi, L., Su, W., Hu, R. Zircon U-Pb geochronology and elemental and $\mathrm{Sr}-\mathrm{Nd}$ isotope geochemistry of Permian mafic rocks in the Funing area, SW China. Contributions to Mineralogy and Petrology. 2005, 151: 1-19.

[59]. Pi, Q. H., Hu, R. Z., Xiong, B., Li, Q. L., Zhong, R. C. In situ SIMS U-Pb dating of hydrothermal rutile: reliable age for the Zhesang Carlin-type gold deposit in the golden triangle region, SW China. Mineralium Deposita. 2017, 52: 1179-1190.

[60]. Chen, C., He, B., Gu, X. Relationship between evolution of the youjiang sedimentary basin and metallogenesis of micro-disseminated gold deposits. Geology and prospecting. 2004, 40: 21-25 (in Chinese).

[61]. WenDou, D., NengPing, S., WenChao, S., JiaLi, C. Study on the ore-forming fluid geochemistry of the Anna gold deposit in southeastern Yunnan Province, China. Acta Petrologica Sinica. 2016, 32: 10 .

[62]. Mingcong, W., ZhuXia, L., Yanlin, M., Peihua, S. Geological Features and Genesis of the Laozhaiwan Gold Deposit in Southeastern Yunnan Province. Geology and Exploration. 2011, 47: 261-267.

[63]. Zhao, D., Chen, C., Gu, X., Li, B., Dai, H. Geochemical characteristics of trace and rare earth elements in the Laozhaiwan gold deposit, Yunnan. Mineral Deposits. 2012, 31: 463-464.

[64]. Cuihua, C., Dekun, Z., Xuexiang, G., Hongzhang, D. Discussion on Ore-forming Material Sources of the Laozhaiwan Gold Deposit, Yunnan. Bulletin of mineralogy, and petrology and geochemistry. 2014, 33: 23-30 (in Chinese).

[65]. Hu, R., Fu, S., Huang, Y., Zhou, M. F., Fu, S., Zhao, C., Wang, Y., Bi, X., Xiao, J. The giant South China Mesozoic low-temperature metallogenic domain: Reviews and a new geodynamic model. Journal of Asian Earth Sciences. 2017b, 137: 9-34. 
[66]. Hu, R. Z., Chen, W. T., X, D. R., Zhou, M. F. Reviews and new metallogenic models of mineral deposits in South China: An introduction. Journal of Asian Earth Sciences. 2017a, 137 $1-8$.

[67]. Zhu, J., Zhong, H., Xie, G., Zhao, C., Xu, L., Lu, G. Origin and geological implication of the inherited zirconfrom felsic dykes, Youjiang basin, China. Acta Petrologica Sinica. 2016, 32: 3269-3280.

[68]. Qi, Y., Hu, R., Zhang, H., Ren, G., Wu, L., Zhu, J., Wang, X., Meng, C., Jin, X. Zircon U-Pb Geochronology and Geochemical Characteristics of The Mafic Intrusions in Northwestern Guizhou Province, and Their Significances to the Lead-Zinc Mineralization. Acta geologica sinica. 2016, 90: 933-949.
[69]. Hu, R., Fu, S., Xiao, J. Major scientific problems on low-temperature metallogenesis in South China. Acta Petrologica Sinica. 2016, 32: 3239-3251 (in Chinese).

[70]. Peng, J., Hu, R. Metallogenic epoch and metallogenic tectonicenvironment of antimony deposits, south china. Geology-geochemistry. 2001, 29: 104-108.

[71]. Chen, M., Mao, J., Li, C., Zhang, Z., Dang, Y. Re-Os isochron ages for arsenopyrite from Carlin-like gold deposits in the Yunnan-Guizhou-Guangxi "golden triangle", southwestern China. Ore Geology Reviews. 2015a, 64: 316-327.

[72]. Chen, M., Mao, J., Li, C., Zhang, Z., Dang, Y. Genetic types of phyllosilicate (micas) and its ${ }^{39} \mathrm{Ar}^{40} \mathrm{Ar}$ dating in Lannigou gold deposit, Guizhou Province, China. Acta Mineral Sin. 2009, 29: 353-362 (in Chinese with English abstract). 